\title{
In-vitro Anthelmintic activity of Smilax myosotiflora Plant (locally known as Ubi Jaga) Extracts Against Haemonchus contortus Worms in Goats
}

\author{
Wahab A. Rahman*, Yong Chow Fatt \& Shaida Fariza Sulaiman \\ School of Biological Sciences, Universiti Sains Malaysia, 11800 Penang \\ *arawahab@usm.my (Corresponding author). \\ Received on $25^{\text {th }}$ May 2010, accepted in revised form $16^{\text {th }}$ July 2010.
}

\begin{abstract}
This study was conducted to evaluate the in-vitro anthelmintic activity of Smilax myosotiflora plant (locally known as ubi jaga) extract against third-stage Haemonchus contortus larvae from goats. Two trials were conducted, whereby each trial followed similar protocols in which Smilax leaves were extracted using methanol solution. The larvae were than tested with different concentrations of the extract. Smilax plant extract was effective against worm larvae in goats. A $100 \%$ mortality had been achieved at 5 $\mathrm{mg} / \mathrm{ml}$ of concentration.
\end{abstract}

(Keywords: in-vitro, Smilax myosotiflora, Haemonchus contortus, goats)

\section{INTRODUCTION}

Goats and sheep have numerous gastrointestinal parasites which can cause reduced growth rates, weight loss, unthriftiness, diarrhoea, decrease in feed utilization, and death. Several species contribute to parasitism in sheep, Haemonchus contortus, being the most devastating species, because of its blood-sucking behaviour.

There is extensive information available on the use of plants in traditional veterinary medicine, and researchers such as Hammond et al. (1997) have presented excellent reviews on the potential of using plant anthelmintics. Studies in Malaysia and Philippines reported the activity of Azadirachta indica (Neem plant) against nematode parasites in ruminants (Baldo 2001; Chandrawathani el al. 2002). Also, cattle provided with feed blocks containing different levels of dried leaves of $A$. indica had significantly lower faecal worm egg counts.

Smilax myosotiflora with the local common name of Ubi Jaga, is a herbaceous climber with slender smooth stem and branches. From recent studies, the extracts of Smilax china roots were reported to have high levels of radical scavenging activity to inhibit lipid peroxidation and enhance the effects of various antioxidant enzymes (Chen $e t$ al., 1999). Smilax rhizomes have various pharmacological activities (Ban et al. 2006), such as immunomodulatory (Jiang \& Xu, 2003), antibacterial, antifungal, antioxidant and hepatoprotective (Chen et al. 1999).

However, very little is known on the use of Smilax plant on controlling endoparasites and its use as anthelmintics has not been tested. This present research was carried out to test the presence of anthelmintic activity, if any, of the
Smilax plant extract against $H$. contortus nematodes from goats.

\section{MATERIALS AND METHODS}

Culturing of third-stage trichostrongylid worm larvae

Fresh goat faeces were collected per rectum from a farm in Penang and kept in sealed plastic bags and specimen bottles and taken back to the laboratory for cultures. Using a spatula, faecal samples were broken into pieces in a Petri dish partially filled with distilled water. The faecal mesh was then smeared onto one side of wet filter papers cut into $14 \times 2 \mathrm{~cm}$ size, leaving about 4 $\mathrm{cm}$ of both ends of the paper free of any faecal smear.

Each piece of filter paper was then rolled and placed into a glass test tube filled with about $3 \mathrm{ml}$ of distilled water. The test tube was then closed with a rubber stopper and incubated at $30^{\circ} \mathrm{C}$ for 11 days.After incubation, the filter paper was removed from the test tube. The sides of the test tube were washed with distilled water so that any larvae that might be found on its sides would be washed down to the bottom of the test tube. Trichostrongylid larvae were sucked up using a pipette and used in the experiment.

\section{Preparation of Smilax plant extract}

The S. myosotiflora plant used in this research was obtained at the Herbal Garden of School of Biological Sciences in University Science of Malaysia. The main four parts of the plant i.e stems, tendrils, leaves and thorns were used for the extraction. The plant was cut and crushed to smaller pieces using a grinder. Extraction was carried out in a $100 \mathrm{ml}$ flask where the crushed 
Smilax and 500ml of methanol were stirred for 1 hour at $60^{\circ} \mathrm{C}$. It was filtered through filter paper (Whatman No. 40) after leaving the methanolic solution to cool. The filtrate was then freeze-dried overnight.

Extract concentrations of the Smilax plant $(1 \mathrm{mg} / \mathrm{ml}, 2 \mathrm{mg} / \mathrm{ml}, 3 \mathrm{mg} / \mathrm{ml}, 4 \mathrm{mg} / \mathrm{ml}$ and $5 \mathrm{mg} / \mathrm{ml})$ were prepared by using an electrical weighing machine. Extractions of different concentrations were placed in separate Eppendorf tubes. Distilled water was added to the extractions in the Eppendorf tubes and shaken till the extractions were dissolved. Each Eppendorf tube was labelled according to its respective concentration. The anthelmintic activity was determined in 3 replicates for each concentration.

A 24-well microtitre plate was used when testing the efficacy of the extract against the trichostrongylid larvae of different concentrations in 3 replicates each time it was carried out. A total of 18 wells were used including the 3 replicates as experimental controls. The wells were labelled according to different concentrations used.

In-vitro testing of Smilax extract against trichostrongylid larvae

Ten trichostrongylid worms of similar size from the above culture were placed in each well. Prepared extractions of the Smilax plant were then being poured into the wells according to their respective concentrations. The mortality of the worms was recorded at intervals of 24, 48, 72 and $96 \mathrm{hr}$ after treatment. The microtitre plate was shaken lightly for a while before observation was made. Three trials were carried out for each concentration and the mean value recorded.

\section{Statistical Analysis}

Statistical analysis were performed with the Statistical Programs fro the Social Science (SPSS) version 11.5. Data satisfied the assumptions of the general linear model and were not transformed. Statistical significance of data was assessed by analysis of variance (ANOVA). When ANOVA indicated there were significant effects $(p<0.05)$, the Tukey test was used to compare the means.

\section{RESULTS}

Some mortality in larvae could be seen after being treated with Smilax extraction for $24 \mathrm{hr}$ (Table 1). The percentage of mortality of treated larvae reached as high as $90 \%$ for $3 \mathrm{mg} / \mathrm{ml}, 4$ $\mathrm{mg} / \mathrm{ml}$, and $5 \mathrm{mg} / \mathrm{ml}$ concentrations. However, there was $7 \%$ mortality for the untreated larvae or control.After $48 \mathrm{hr}$, there were increases in mortality for extract concentrations of $1 \mathrm{mg} / \mathrm{ml}, 2$ $\mathrm{mg} / \mathrm{ml}, 5 \mathrm{mg} / \mathrm{ml}$ as well as the control except for $3 \mathrm{mg} / \mathrm{ml}$ and $4 \mathrm{mg} / \mathrm{ml}$ which still recorded $90 \%$ mortality. However, mortality of treated larvae for concentration of $5 \mathrm{mg} / \mathrm{ml}$ had reached $100 \%$ (Table 2). There was $13 \%$ mortality rate for control larvae.

Increases in mortality still occurred after $72 \mathrm{hr}$ for every extract concentration including control, except for $4 \mathrm{mg} / \mathrm{ml}$. The extract concentration of $3 \mathrm{mg} / \mathrm{ml}$ recorded $93 \%$ of mortality. It was higher than the mortality rate from $4 \mathrm{mg} / \mathrm{ml}$ (Table 3 ). Table 4 showed that there were increases on mortality percentages for all treated larvae while the mortality of the larvae from control did not change (Table 4). The concentration of $3 \mathrm{mg} / \mathrm{ml}$ recorded $97 \%$ mortality and was still higher than at concentration $4 \mathrm{mg} / \mathrm{ml}$ which recorded $93 \%$ mortality. The controls showed similar mortalities at both $72 \mathrm{hr}$ and $96 \mathrm{hr}$ of exposure to the plant extract.

After $120 \mathrm{hr}$, the mortality of control had reached $20 \%$ while both concentrations of $3 \mathrm{mg} / \mathrm{ml}$ and 4 $\mathrm{mg} / \mathrm{ml}$ remained at the same mortality as after 96 hr which were $97 \%$ and $93 \%$ respectively (Table 5). Mortality at concentration of $2 \mathrm{mg} / \mathrm{ml}$ recorded $93 \%$ after $120 \mathrm{hr}$, which was similar at concentration $4 \mathrm{mg} / \mathrm{ml}$. At $5 \mathrm{mg} / \mathrm{ml}$ concentration of extract Smilax, $100 \%$ mortality rate to larvae was recorded and proved to be the most effective.

Figures 1 to 5 showed the percentages of mean mortality of trichostrongylid larvae after being treated with the different concentrations of Smilax plant from all the results of three trials that had been recorded. The figures also showed the significant difference for the different concentrations treated on the larvae.

There was no significant difference between concentrations $3 \mathrm{mg} / \mathrm{ml}, 4 \mathrm{mg} / \mathrm{ml}$, and $5 \mathrm{mg} / \mathrm{ml}$ (Figure 1). These three concentrations were significantly different with concentrations 1 $\mathrm{mg} / \mathrm{ml}$ and $2 \mathrm{mg} / \mathrm{ml}$, as well as the control while $1 \mathrm{mg} / \mathrm{ml}$ and $2 \mathrm{mg} / \mathrm{ml}$ concentrations also showed significant difference with control.

After $48 \mathrm{hr}$, there was significant difference between the mortality rate at concentrations 3 $\mathrm{mg} / \mathrm{ml}$ and $5 \mathrm{mg} / \mathrm{ml}$ and no significant difference was seen between concentrations $2 \mathrm{mg} / \mathrm{ml}$ and, 3 $\mathrm{mg} / \mathrm{ml}$ and $4 \mathrm{mg} / \mathrm{ml}$ which did not happen from the $24 \mathrm{hr}$ period (Figure 2).

The same situation happened to the mortality rate from the $72 \mathrm{hr}$ though the mortality rates of every concentration became higher including control (Figure 3). 
Table 1: Mortality rate of trichostrongylid larvae treated with different concentrations of Smilax plant extract after $24 \mathrm{hr}$

\begin{tabular}{|c|c|c|c|c|c|c|c|}
\hline \multirow{3}{*}{$\begin{array}{c}\text { Extract } \\
\text { concentration } \\
(\mathrm{mg} / \mathrm{ml})\end{array}$} & \multicolumn{7}{|c|}{ Mortality of larvae after $24 \mathrm{hr}$} \\
\hline & \multicolumn{3}{|c|}{ Replicates } & \multirow[t]{2}{*}{ Total } & \multirow[t]{2}{*}{$(\%)$} & \multirow[t]{2}{*}{ Mean } & \multirow{2}{*}{$\mathrm{SE}( \pm)$} \\
\hline & 1 & 2 & 3 & & & & \\
\hline 0 & 1 & 0 & 1 & 2 & 7 & 0.67 & 0.48 \\
\hline 1 & 7 & 8 & 4 & 19 & 63 & 6.33 & 1.45 \\
\hline 2 & 8 & 7 & 5 & 20 & 67 & 6.67 & 1.49 \\
\hline 3 & 9 & 9 & 9 & 27 & 90 & 9.00 & 1.73 \\
\hline 4 & 9 & 10 & 8 & 27 & 90 & 9.00 & 1.73 \\
\hline 5 & 9 & 9 & 9 & 27 & 90 & 9.00 & 1.73 \\
\hline
\end{tabular}

Table 2: Mortality rate of trichostrongylid larvae treated with different concentrations of Smilax plant extract after $48 \mathrm{hr}$

\begin{tabular}{|c|c|c|c|c|c|c|c|}
\hline \multirow{2}{*}{$\begin{array}{c}\text { Extract } \\
\begin{array}{c}\text { concentration } \\
(\mathrm{mg} / \mathrm{ml})\end{array}\end{array}$} & \multicolumn{7}{|c|}{ Mortality of larvae after $48 \mathrm{hr}$} \\
\cline { 2 - 7 } & \multicolumn{3}{|c|}{ Replicates } & Total & $(\%)$ & Mean & SE $( \pm)$ \\
\cline { 2 - 7 } & 1 & 2 & 3 & & & & \\
\hline 0 & 1 & 1 & 2 & 4 & 13 & 1.33 & 0.67 \\
1 & 7 & 8 & 6 & 21 & 70 & 7.00 & 1.53 \\
2 & 10 & 8 & 6 & 24 & 80 & 8.00 & 1.63 \\
3 & 9 & 9 & 9 & 27 & 90 & 9.00 & 1.73 \\
4 & 9 & 10 & 8 & 27 & 90 & 9.00 & 1.73 \\
5 & 10 & 10 & 10 & 30 & 100 & 10.00 & 1.82 \\
& & & & & & & \\
\hline
\end{tabular}

Table 3: Mortality rate of trichostrongylid larvae treated with different concentrations of Smilax plant extract after $72 \mathrm{hr}$

\begin{tabular}{|c|c|c|c|c|c|c|c|}
\hline \multirow{3}{*}{$\begin{array}{c}\text { Extract } \\
\text { concentration } \\
(\mathrm{mg} / \mathrm{ml})\end{array}$} & \multicolumn{7}{|c|}{ Mortality of larvae after $72 \mathrm{hr}$} \\
\hline & \multicolumn{3}{|c|}{ Replicates } & \multirow[t]{2}{*}{ Total } & \multirow[t]{2}{*}{$(\%)$} & \multirow[t]{2}{*}{ Mean } & \multirow[t]{2}{*}{$\mathrm{SE}( \pm)$} \\
\hline & 1 & 2 & 3 & & & & \\
\hline 0 & 1 & 2 & 2 & 5 & 17 & 1.67 & 0.75 \\
\hline 1 & 8 & 8 & 6 & 22 & 73 & 7.33 & 1.56 \\
\hline 2 & 10 & 9 & 6 & 25 & 83 & 8.33 & 1.67 \\
\hline 3 & 10 & 9 & 9 & 28 & 93 & 9.33 & 1.76 \\
\hline 4 & 9 & 10 & 8 & 27 & 90 & 9.00 & 1.73 \\
\hline 5 & 10 & 10 & 10 & 30 & 100 & 10.00 & 1.82 \\
\hline
\end{tabular}


Table 4: Mortality rate of trichostrongylid larvae treated with different concentrations of Smilax plant extract after $96 \mathrm{hr}$

\begin{tabular}{|c|c|c|c|c|c|c|c|}
\hline \multirow{3}{*}{$\begin{array}{c}\text { Extract } \\
\text { concentration } \\
(\mathrm{mg} / \mathrm{ml})\end{array}$} & \multicolumn{7}{|c|}{ Mortality of larvae after $96 \mathrm{hr}$} \\
\hline & \multicolumn{3}{|c|}{ Replicates } & \multirow[t]{2}{*}{ Total } & \multirow[t]{2}{*}{$(\%)$} & \multirow[t]{2}{*}{ Mean } & \multirow[t]{2}{*}{$\mathrm{SE}( \pm)$} \\
\hline & 1 & 2 & 3 & & & & \\
\hline 0 & 1 & 2 & 2 & 5 & 17 & 1.67 & 0.75 \\
\hline 1 & 9 & 10 & 6 & 25 & 83 & 8.33 & 1.67 \\
\hline 2 & 10 & 9 & 8 & 27 & 90 & 9.00 & 1.73 \\
\hline 3 & 10 & 10 & 9 & 29 & 97 & 9.67 & 1.79 \\
\hline 4 & 9 & 10 & 9 & 28 & 93 & 9.33 & 1.76 \\
\hline 5 & 10 & 10 & 10 & 30 & 100 & 10.00 & 1.82 \\
\hline
\end{tabular}

Table 5: Mortality rate of trichostrongylid larvae treated with different concentrations of Smilax plant extract after $120 \mathrm{hr}$

\begin{tabular}{|c|c|c|c|c|c|c|c|}
\hline \multirow{3}{*}{$\begin{array}{c}\text { Extract } \\
\text { concentration } \\
(\mathrm{mg} / \mathrm{ml})\end{array}$} & \multicolumn{7}{|c|}{ Mortality of larvae after $120 \mathrm{hr}$} \\
\hline & \multicolumn{3}{|c|}{ Replicates } & \multirow[t]{2}{*}{ Total } & \multirow[t]{2}{*}{$(\%)$} & \multirow[t]{2}{*}{ Mean } & \multirow[t]{2}{*}{$\mathrm{SE}( \pm)$} \\
\hline & 1 & 2 & 3 & & & & \\
\hline 0 & 1 & 3 & 2 & 6 & 20 & 2.00 & 0.82 \\
\hline 1 & 9 & 10 & 7 & 26 & 87 & 8.67 & 1.70 \\
\hline 2 & 10 & 10 & 8 & 28 & 93 & 9.33 & 1.76 \\
\hline 3 & 10 & 10 & 9 & 29 & 97 & 9.67 & 1.79 \\
\hline 4 & 9 & 10 & 9 & 28 & 93 & 9.33 & 1.76 \\
\hline 5 & 10 & 10 & 10 & 30 & 100 & 10.00 & 1.82 \\
\hline
\end{tabular}

However, there were no significant differences observed from concentrations $3 \mathrm{mg} / \mathrm{ml}$ and 4 $\mathrm{mg} / \mathrm{ml}$, as well as concentrations $1 \mathrm{mg} / \mathrm{ml}$ and 2 $\mathrm{mg} / \mathrm{ml}$ (Figures $1 \& 2$ ). The mortality rate for concentration $5 \mathrm{mg} / \mathrm{ml}$ showed no significant difference to both $3 \mathrm{mg} / \mathrm{ml}$ and $4 \mathrm{mg} / \mathrm{ml}$ though only $3 \mathrm{mg} / \mathrm{ml}$ and $4 \mathrm{mg} / \mathrm{ml}$ showed significant difference to concentration $2 \mathrm{mg} / \mathrm{ml}$.

There were significant differences observed between control and other concentrations (Figure 2).After $120 \mathrm{hr}$, there were no significant difference observed between $2 \mathrm{mg} / \mathrm{ml}, 3 \mathrm{mg} / \mathrm{ml}, 4$ $\mathrm{mg} / \mathrm{ml}$, and $5 \mathrm{mg} / \mathrm{ml}$ concentrations (Figure 5). However, $2 \mathrm{mg} / \mathrm{ml}$ was significantly different from $1 \mathrm{mg} / \mathrm{ml}$ while concentrations of $3 \mathrm{mg} / \mathrm{ml}, 4$ $\mathrm{mg} / \mathrm{ml}$, and $5 \mathrm{mg} / \mathrm{ml}$ showed significant differences to that of $1 \mathrm{mg} / \mathrm{ml}$.

\section{DISCUSSION}

The present study indicated that Smilax plant extract was effective against trichostrongylid larvae of the goats. The percentage reduction of the larvae gave an indication of how effective the extraction of Smilax plant was at specifically being used as an antihelmintic.

A $100 \%$ of mortality rate had been achieved at 5 $\mathrm{mg} / \mathrm{ml}$ of concentration. Although many traditional plants had been proved being active towards nematode parasites, using Smilax plant is still a new approach as an anthelmintic to nematode parasite control. There is little information available addressing the mechanism behind how the Smilax plant affects trichostrongylid larvae and other abomasal nematodes. However, Smilax plant proved to be effective against infective third stage trichostrongylid ${ }_{3}$ larvae. 


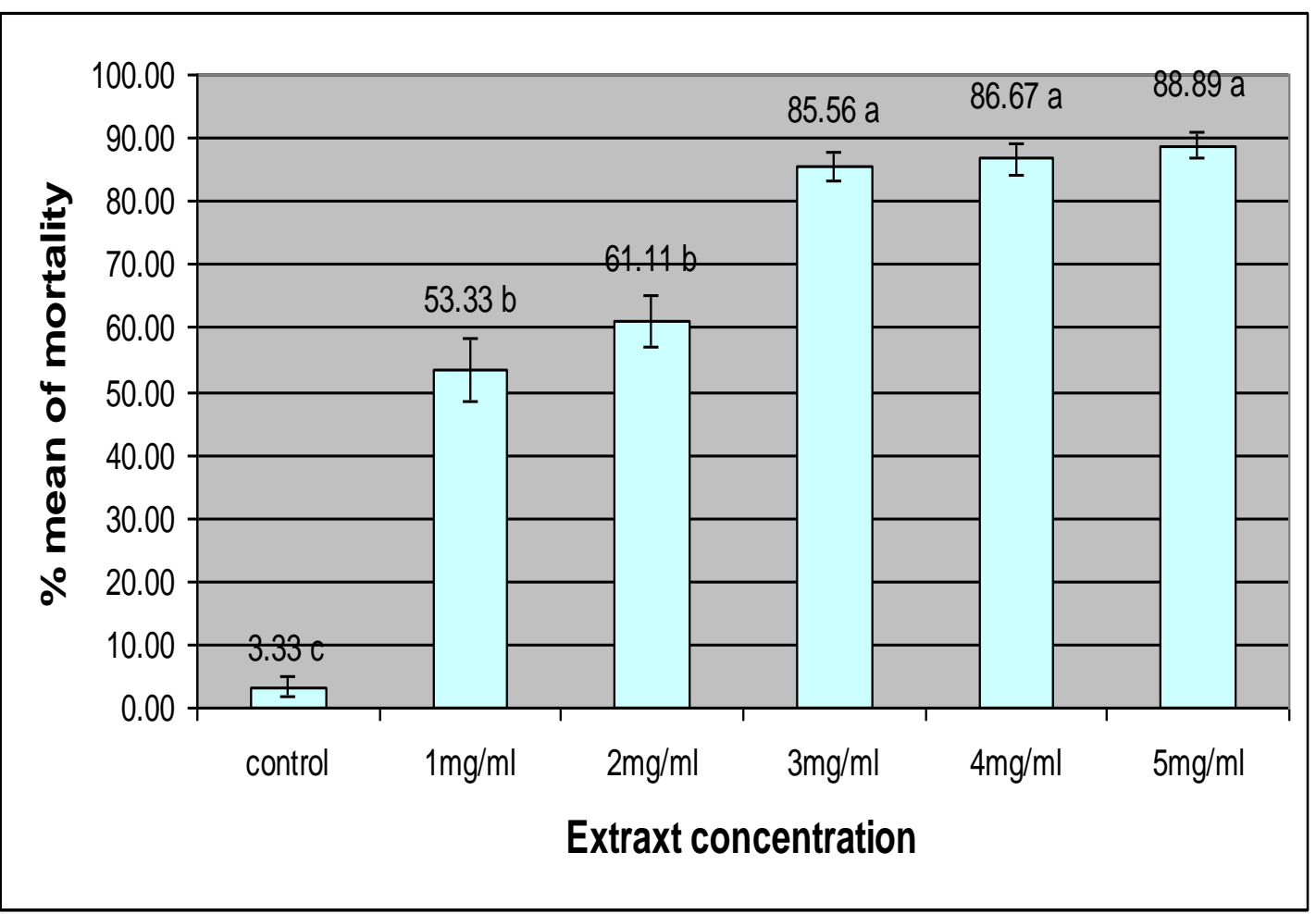

Means followed by a common letter do not differ significantly (Tukey’s test, $\mathrm{p}<0.05$ ).

Figure 1: Effect of exposure to extracts of Smilax plant on the mortality of trichostrongylid larvae during the $24 \mathrm{hr}$ of treatment

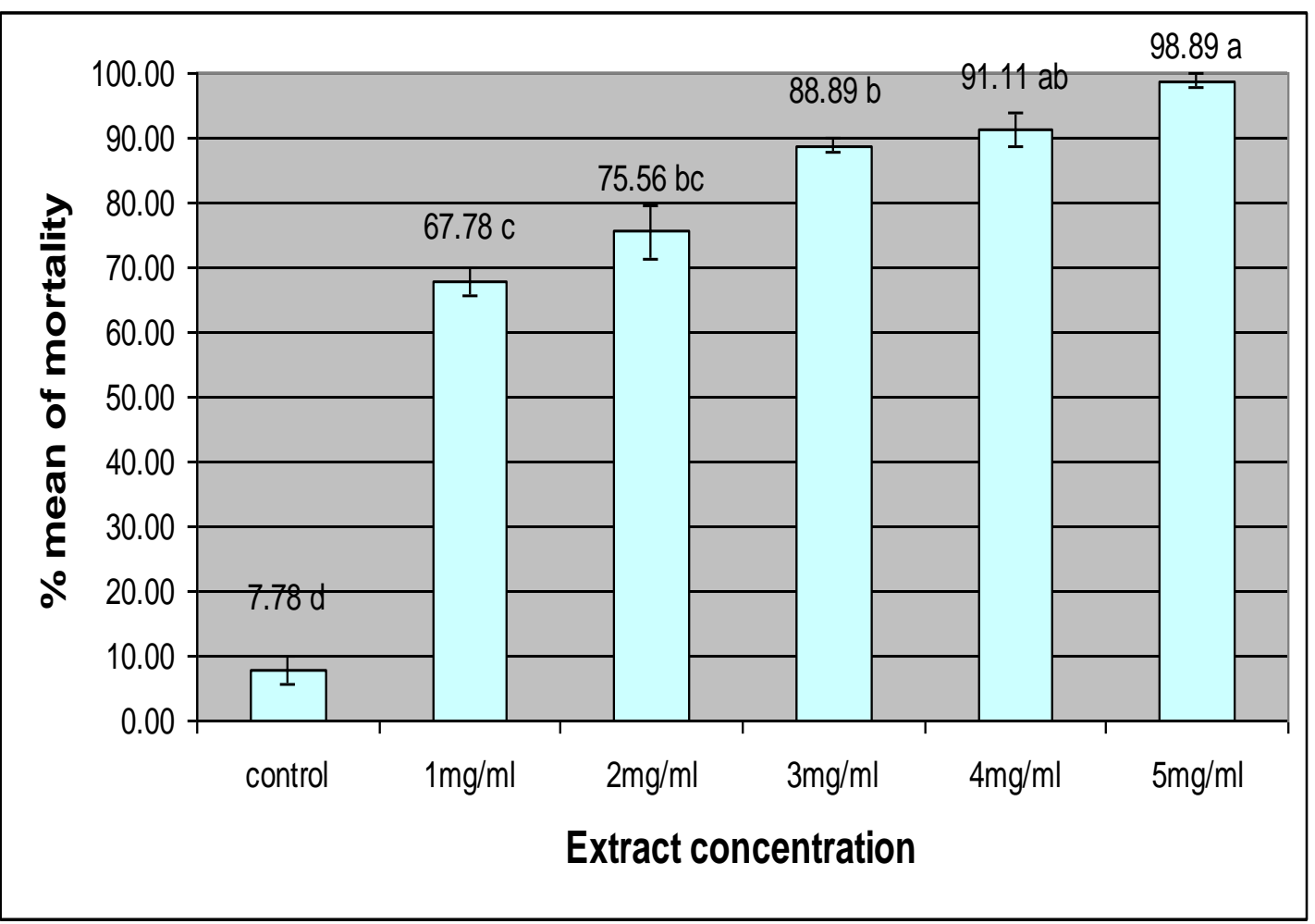

Means followed by a common letter do not differ significantly (Tukey’s test, $\mathrm{p}<0.05$ ).

Figure 2: Effect of exposure to extracts of Smilax plant on the mortality of trichostrongylid larvae during the $48 \mathrm{hr}$ of treatment 


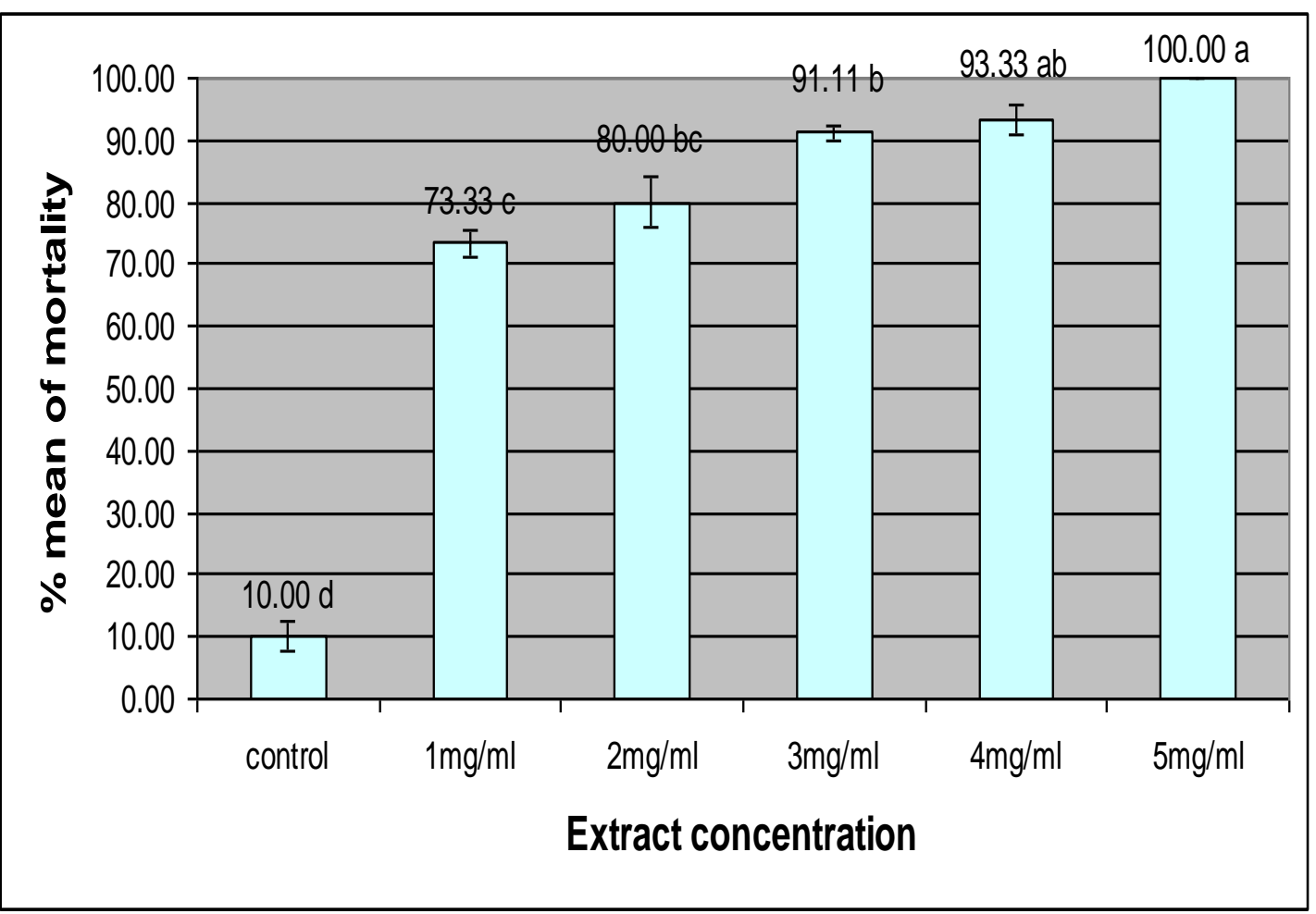

Means followed by a common letter do not differ significantly (Tukey’s test, $\mathrm{p}<0.05$ ).

Figure 3: Effect of exposure to extracts of Smilax plant on the mortality of trichostrongylid larvae during the $72 \mathrm{hr}$ of treatment

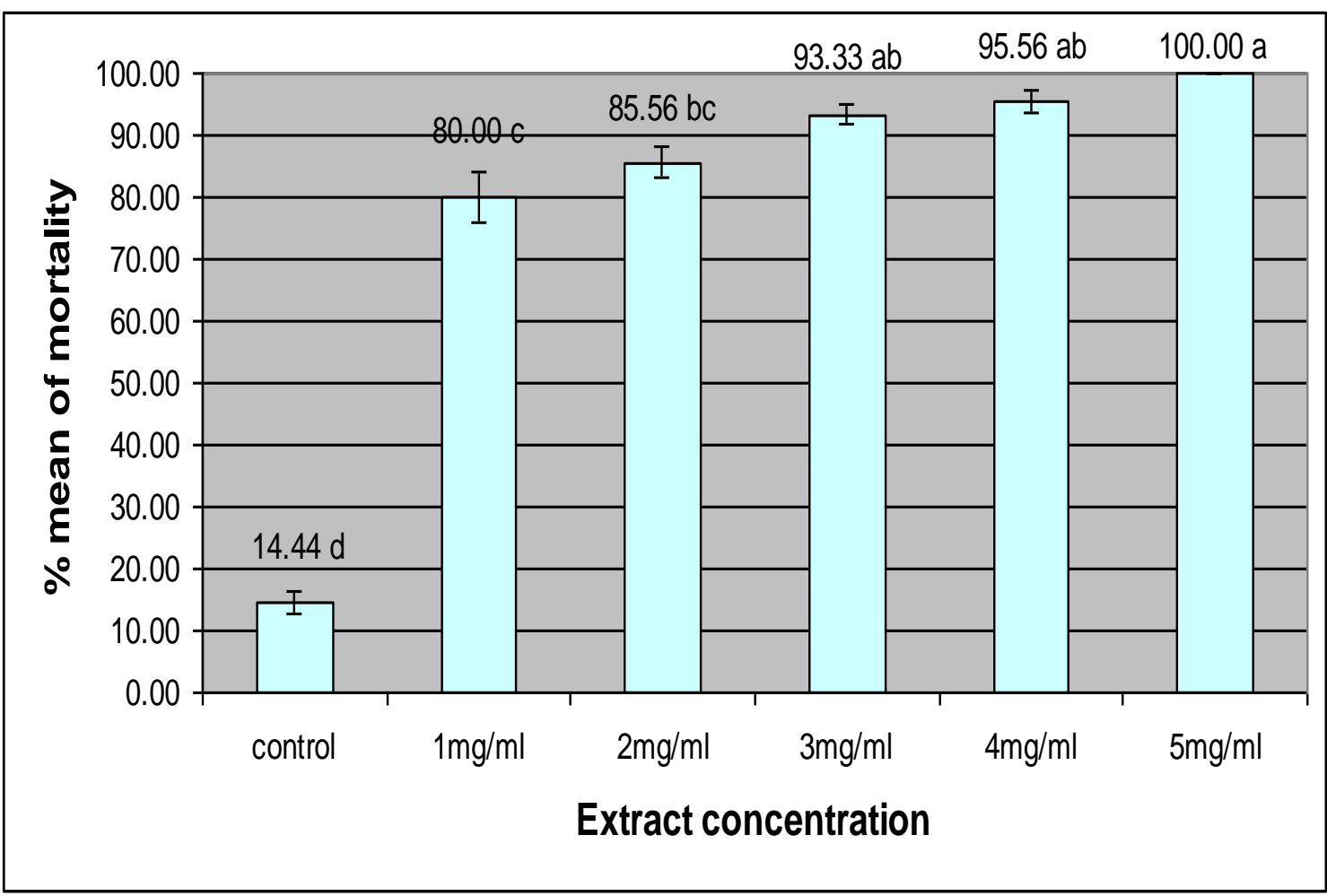

Means followed by a common letter do not differ significantly (Tukey's test, $\mathrm{p}<0.05$ ).

Figure 4: Effect of exposure to extracts of Smilax plant on the mortality of trichostrongylid larvae 
during the $96 \mathrm{hr}$ of treatment

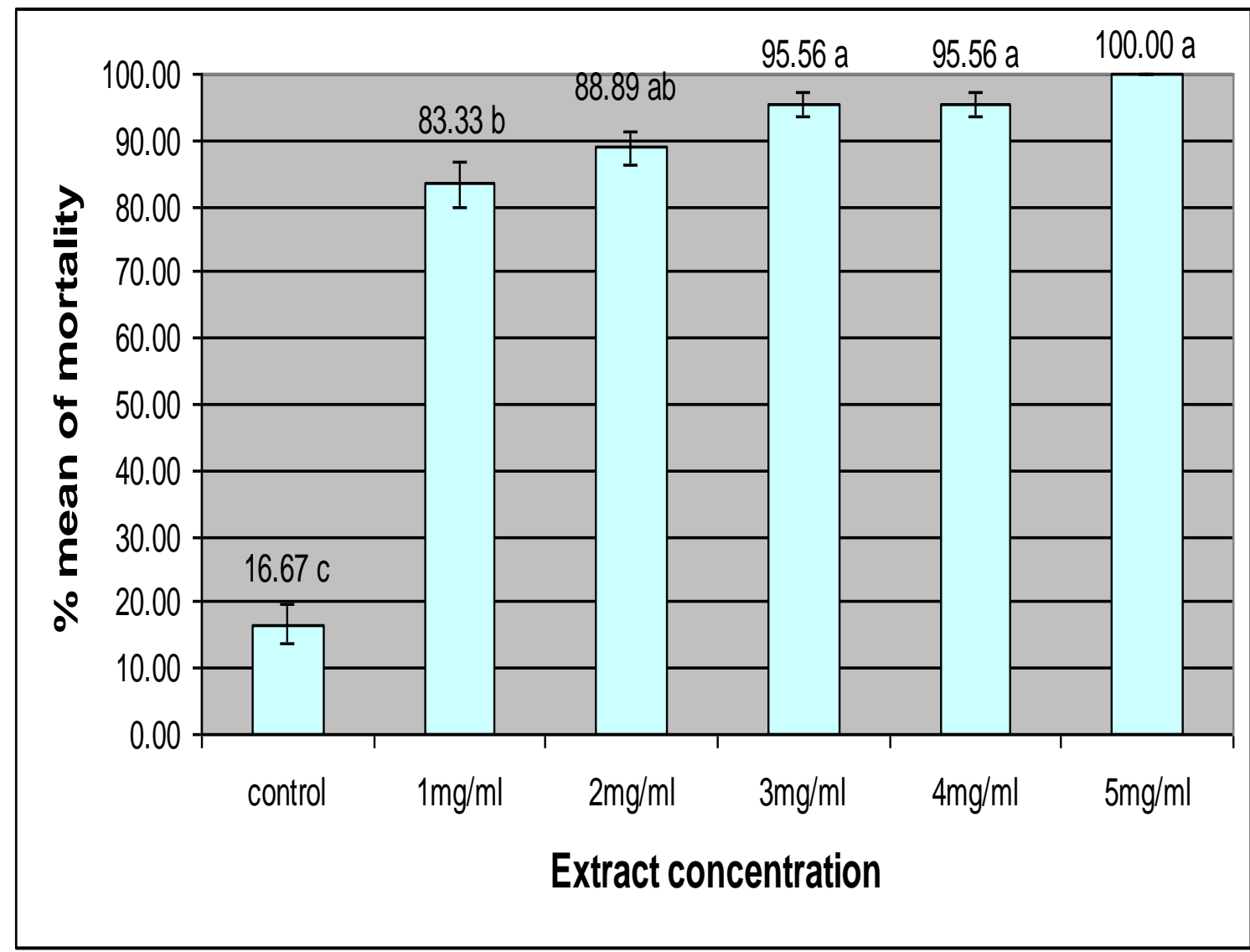

Means followed by a common letter do not differ significantly (Tukey’s test, $\mathrm{p}<0.05$ ).

Figure 5: Effect of exposure to extracts of Smilax plant on the mortality of trichostrongylid larvae during the $120 \mathrm{hr}$ of treatment

Therefore, there are several assumptions to be made on the contributions of the Smilax plant that could possibly bring to control nematode parasites. When the goats and sheep were treated with Smilax plant, the number of larvae would be reduced.

Thus, the infection levels in the grazing host would consequently be reduced and causes fewer eggs being passed out in the faeces. Therefore, this lowered egg output, decreases the percentage of larvae on pasture available to infect the grazing animals, and so the overall free-living population is reduced. Treatment with Smilax plant extract showed a high mortality in the trial.

However, additional research needs to be conducted before Smilax plant could be safely and effectively used in an integrated parasite control program for goats and sheep. Besides, studies to determine the mode of action of the Smilax plant on the gastrointestinal parasites are needed to help maximizing the use of the plant as an anthelmintic.
However, the use of Smilax plant in conjunction with other control methods may be a useful tool for producers and help reduce reliance on the conventional use of anthelmintics for control.

\section{CONCLUSIONS}

Many traditional plants had been proved to be active against various species of nematode parasites. In the present study Smilax plant extract was shown to be effective against Haemonchus contortus in goats. In fact, $100 \%$ mortality had been achieved at $5 \mathrm{mg} / \mathrm{ml}$ of concentration.

Perhaps in the near future, the efficacy of this same plant could also be tested on other groups of nematode parasites to see its effectiveness.

\section{REFERENCES}

1. Baldo, R. C., 2001. Comparative efficacy of pineapple (Ananas comosus) leaves bolus and albendazole againse gastrointestinal nematodes of Sheep. DVM. University of the Pholipines, Department of Veterinary Parasitology. 38 pp. 
2. Ban, J. Y., Cho, S. O., Koh, S. B., Song, K-S., Bae, K. \& Seong, Y. H., 2006. Protection of amyloid . protein-induced neurotoxicity by methanol extract of Smilax chinae rhizome in cultured rat cortical neurons. Journal of Ethnopharmacology, 106, 230-237 pp.

3. Barriga, O.O, 1997. Veterinary Parasitology for Practitioners (2nd ed.), Burgress Publishing. $354 \mathrm{pp}$.

4. Chandrawathani, P., Brelin, D., Nor Fasiha, A.S., Adnan, M., Jamnah, O., Rehana, A.S., Hoglund, J. \& Waller, P. J., 2002. Evaluation of the neem tree (Azadirachta indica) as a herbal anthelmintic for nematode parasite control in small remimants in Malaysia. Tropical Biomedicine 19, 41-48 pp.

5. Chen, T., Li, J., Cao, J., Xu, Q., Komatsu, K. \& Namba, T., (1999). A new flavanone isolated from rhizome of Smilax glabrae and the structural requirements of its derivatives for preventing immunological hepatocyte damage. Planta Medica, 65, 56-59 pp.

6. Hammond, J.A., D. Fielding and S.C. Bishop. 1997. Prospects for plant anthelmintics in tropical veterinary medicine. Veterinary Research Communications. 21 (3):213-228 pp.

7. Jiang, J. \& Xu, Q. 2003. Immunomodulatory activity of the aqueous extract from rhizome of Smilax glabra in the later phase of adjuvantinduced arthritis in rats. Journal of Ethnopharmacology, 85, 53-59 pp.

8. Kaplan, R.M. 2004. Drug resistance in nematodes of veterinary importance: a status report. Trends Parasitol. 20, 477-481 pp.

9. Mascie-Taylor C.G.N. and Karim. 2003. The burden of chronic disease. Science, (302). 1921-1922 pp.
10. Pietrosemoli, L. M., 2001. Altividade ovicida in vitro de plantas medicinais contra Haemonchus contortus. Universidade Estadual do Ceara', Fortaleza, Brasil. 68pp.

11. Perry, B. D., Randolph, T. F., McDermott, J. J., Sones, K. R. \& Thornton, P. K. 2002. Investing in animal health research to alleviate poverty. ILRI (International Livestock Research Institute), Nairobi, Kenya, 148 pp. ISBN 9291461083

12. Roos, M.H. 1997. The role of drugs in the control of parasitic nematode infections: must we do without? Parasitology, 137-144 pp.

13. Smith, N.E. and D.M. Sherman. 1994. Goat Medicine. Lea and Febiger, Philadephia. 141$144 \mathrm{pp}$.

14. Waller, P.J. 1997. Nematode parasite control of livestock in the tropics/subtropics: the need for novel approaches. International Journal for Parasitology, 27:1193-1201 pp.

15. Waller, P.J. 1999. International approaches to the concept of integrated control of nematode parasites in livestock. International Journal for Parasitology, 29:155-164 pp.

16. Waller, P.J. 2003. The future of anthelmintics in sustainable parasite control programs for livestock. Helminthologia. 40, 97-102 pp.

17. Veale, P.I. 2002. Resistance to macrocyclic lactones in nematodes of goats.Australian Veterinary Journal, 303-304 pp.

18. Zajac, A.M., Gipson, T.A. 2000. Multiple anthelmintic resistance in a goat herd. Veterinary Parasitology, 163-172 pp. 